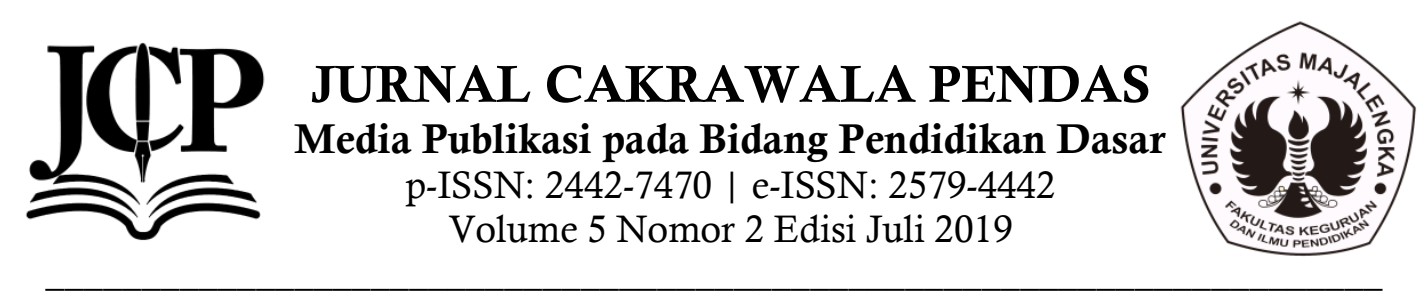

\title{
PENERAPAN MODEL PEMBELAJARAN PROBLEM BASED LEARNING (PBL) UNTUK MENINGKATKAN HASIL BELAJAR DAN BERPIKIR KRITIS MATEMATIKA
}

\author{
Dina Ayuningsih ${ }^{1}$, Firosalia Kristin ${ }^{2}$,Indri Anugraheni ${ }^{3}$ \\ 292015024@student.uksw.edu, firosalia.kristin@uksw.edu, indri.anugraheni@uksw.edu \\ ${ }^{1}$ Mahasiswa, ${ }^{2,3}$ Dosen PGSD FKIP UKSW
}

\begin{abstract}
Abstrak
Penelitian ini bertujuan untuk meningkatan kemampuan berpikir kritis dan hasil belajar siswa dengan menerapkan model pembelajaran Problem Based Learning (PBL) pada pembelajaran Matematika kelas 5. Jenis penelitian ini adalah Penelitian Tindakan Kelas (PTK).Subjek penelitian ini adalah siswa kelas 5 SDN 1Ngambakrejo.Teknik pengumpulan data menggunakan tes dan non tes.Penelitian ini menggunakan teknik analisis data deskriptif kualitatif dan kuantitatif. Hasil penelitian ini menunjukan adanya peningkatan kemampuan berpikir kritis dan hasil belajar siswa kelas 5 SDN 1 Ngambakrejo setelah diterapkan model pembelajaran Problem Based Learning (PBL). Hal tersebut dibuktikandengan peningkatan pada kemampuan berpikir kritis siswa, yaitu pada tahap siklus I nilai rata-rata 62,3. Selanjutnya pada siklus II mengalami peningkatan nilai rata-rata menjadi 77 . Pada hasil belajar siswa juga terjadi peningkatan, hal tersebut ditunjukan dariketuntasan hasil belajarsiswapada tahap siklus I sebanyak 11 siswa denga persentase 40,7dan semakin meningkat pada siklus II menjadi 19 siswa dengan persentase 70,3.
\end{abstract}

Kata kunci: Problem Based Learning, Berpikir Kritis, Hasil Belajar

\begin{abstract}
The aim of this study is improving critical thinking skill and students' study result by applying Problem Based Learning Model on Mathematic learning at $5^{\text {th }}$ grade student of SD N 1 Ngambakrejo semester 2 in the academic year 2018/2019. The type of this study is Classroom Action Research (CAR). The subject of this study is student of $5^{\text {th }}$ grade of SD Negeri 1 Ngambakreoj. The technique of data collection is using test in the form of questions and observation sheets and non-test in the form of rubrics. This study uses descriptive qualitative and quantitative data analysis techniques. The results of this study is to indicate that there is an enhancement of critical thinking skill and students study result of $5^{\text {th }}$ grade of SD Negeri 1 Ngambakrejo after applying Problem based Learning Models. The matter is proven by the increasing of students' critical thinking, is at the cycle 1 the mean of rubric scoring was 62.3. In the cycle II the mean of rubric scoring is 77. In the study result of students were also increased, it was shown from the completeness of learning outcomes of students in the first cycle as many as 11 students by percentage 40,7 and increased in the second cycle to 19 students by percentage 70,3.
\end{abstract}

Keywords: Problem Based Learning, Critical Thinking, Study Result 


\section{Pendahuluan}

Pendidikan sebagai pranata pembangunan sumber daya manusia yang berperan dalam pembentukan siswa agar menjadi aset bangsa yang diharapkan, supaya menjadi manusia yang produktif. Hal ini sesuai tujuan pendidikan nasional yang telah diterapkan pada Undang-undang RI No 20 tahun 2003 tentang Sistem Pendidikan Nasional yaitu:

"Pendidikan nasional bertujuan mencerdaskan kehidupan bangsa dan mengembangkan manusia Indonesia seutuhnya yaitu manusia yang beriman dan bertaqwa kepada Tuhan Yang Maha Esa dan berbudi pekerti luhur, memiliki pengetahuan dan ketrampilan, kesehatan jasmani dan rohani, kepribadian yang mantap dan mandiri, serta rasa bertanggung jawab kemasyarakatan dan kebangsaan".

Cara untuk mewujudkan tujuan Pendidikan Nasional adalah adanya proses kegiatan belajar mengajar. Kegiatan belajar yang melahirkan unsur-unsur manusiawi adalah sebagai suatu proses dalam rangka mencapai tujuan pengajaran.Dalam pengertian yang lebih luas pendidikan adalah segala pengalaman hidup dalam berbagai lingkungan yang berpengaruh positif bagi perkembangan individu yang berlangsung sejak usia dini berlanjut sampai jenjang pendidikan lebih lanjut bahkan sampai akhir hayat. Sedangkan dalam arti sempit pendidikan identik dengan persekolahan yaitu pendidikan yang berlangsung dalam suatu sekolah atau lembaga pendidikan tertentu yang diperlukan secara sengaja. Pendidikan dilakukan dalam bentuk kegiatan pembelajaran terprogram dan terencana serta bersifat formal (Masitoh, 2009:13-14) . Menurut Pramudita dan Anugraheni (2017:72) Matematika merupakan salah satu cabang ilmu yang menerapkan logika dalam proses berfikirnya. Sebagai suatu ilmu yang bersifat simbolis, matematika tidak akan bermanfaat tanpa logika berfikir yang benar. Matematika adalah pembelajaran yang sangat penting karena dalam kehidupan sehari-hari manusia menggunakan ilmu matematika. Hal yang terpenting dalam pembelajaran matematika yang sedemikian ini adalah pemecahan masalah. Hampir di semua Kompetensi Dasar ditegaskan perlunya kemampuan pemecahan masalah. Maka dari itu terbentuk kesan bahwa matematika merupakan pelajaran yang sulit dan ditakuti siswa, dan kenyataanya memang demikian banyak siswa yang tidak suka dengan matematika dan kurang diminati oleh siswa. Kenyataanya kegiatan pembelajaran matematika di SD N 1 Ngambakrejo pada umumnya sudah berjalan dengan baik dan lancar, namun ditemukan beberapa permasalahan selama proses pembelajaran hal ini terbukti karena belum tercapainya tujuan yang diharapkan pada hasil belajar siswa pada mata pelajaran matematika. Pertama, dari 27 siswa terdapat 21 siswa dengan persentase 77,8 yang belum mencapai nilai diatas KKM dan 6 siswa dengan persentase 22,2 yang sudah mencapai nilai diatas KKM yang telah ditetapkan. Siswa cenderung kurang memahami dalam memecahkan masalah, dalam hal ini siswa tidak tahu tujuan dari soal yang berakibat kesulitan dalam konsep. Ketiga, rendahnya keterampilan siswa dalam penyelesaian soal matematika juga menjadi permasalahan, akar penyebabnya adalah kurangnya buku-buku pendukung untuk referensi soal.

Fenomena atas gejala diatas, dapat dipahami bahwa hasil belajar dan berpikir kritis siswa masih rendah. Maka dapat dikatakan bahwa dalam pembelajaran matematika akan berjalan dengan baik apabila ada aktivitas siswa yang mendukung dalam pembelajaran, seperti aktif bertanya maupun mengemukakan pendapat. Guru sebagai pembimbing berperan aktif dalam pembelajaran. Apabila siswa dan guru aktif maka diharapkan pembelajaran akan lebih baik. Guru juga harus menggunakan model pembelajaran yang dapat menarik perhatian siswa. Model pembelajaran ini diterapkan supaya tercapainya tujuan pembelajaran yang efektif dan efisien sesuai yang diharapkan.

Cara untuk meningkatkan hasil belajar dan berpikir kritis siswa adalah dengan menerapkan model pembelajaran yang dapat memacu siswa untuk beraktivitas didalamnya. Pendekatan pembelajaran yang dapat meningkatkan hasil belajar dan berpikir kritis siswa adalah 
model pembelajaran Problem Besed Learning (PBL). Model pembelajaranProblem Besed Learning $(P B L)$ sering disebut dengan metode eksperimen, metode reflektif, dan metode ilmiah. Menurut Anugraheni (2018:11) Model pembelajaran Problem Based Learning (PBL) dalam model pembelajaran berbasis masalah merupakan suatu model pembelajaran yang melibatkan siswa dalam kegiatan pembelajaran dan mengutamakan permasalahan nyata baik dilingkungan rumah, sekolah, serta masyarakat sebagai dasar untuk memperoleh pengetahuan dan konsep melalui keterampilan kemampuan dalam berfikir kritis dan memecahkan suatu masalah. Model pembelajaran Problem Besed Learning (PBL) menekankan pada aktivitas pemecahan masalah dalam pembelajaran. Melalui model pembelajaran Problem Besed Learning (PBL), siswa belajar melalui aktivitas pemecahan masalah yang dapat mengasah keterampilan berpikir siswa. Hal inilah yang menjadi dasar bahwa model pembelajaranProblem Besed Learning (PBL) merupakan suatu model pembelajaran yang mampu meningkatkan kemampuan berpikir kritis bagi para siswa. Dengan berpikir kritis para siswa akan belajar memecahkan masalah dalam pembelajaran yang dihadapinya dengan cara berpikir secara aktif dan terus menerus mengenai sebuah keyakinan/pengetahuan yang telah diterimanya untuk menghasilkan sebuah jawaban atau gagasan baru. Sehingga mampu meningkatkan hasil belajarnya. Berdasarkan latar belakang tersebut peneliti tertarik untuk melakukan penelitian dengan judul "Penerapan Model Pembelajaran Problem Based Learning (PBL) Untuk Meningkatkan Hasil Belajar dan Berpikir Kritis Mata Pelajaran Matematika Pada Siswa Kelas 5 SDN 1 Ngambakrejo Semester 2".

\section{Metode Penelitian}

Jenis penelitian menggunakan Penelitian Tindakan Kelas PTK. Penelitian ini menggunakan jenis penelitian kuantitatif. Penelitian yang dilaksanakan berfokus pada siswa kelas 5 SDN 1 Ngambakrejo tahun ajaran 2018/2019 semester 2 yang berjumlah 27siswa dengan tingkat kemampuan heterogen. Dalam pe- rencanaan pelaksanaan penelitian yang akan dilakukan oleh peneliti terdapat 2 siklus. Rangkaian Pelaksanaan pada siklus I meliputi kegiatan perencanaan, tindakan, observasi dan refleksi, dilanjutkan dengan siklus II dengan rangkaian kegiatan revisi siklus I, perencanaan, tindakan, observasi dan refleksi.

Teknik Pengumpulan data menggunakan teknik observasi, rubrik dan tes. Lembar observasi memuat indikator penilaian yang berfungsi sebagai pengukur pelaksanaan pembelajaran Matematika dengan penggunaan model Problem Based Learning (PBL) pada aktivitas yang dilakukan oleh guru pengajar dan siswa.

Teknik non tes yang digunakan berupa rubrik berpikir kritis dengan memuat indikator penilaian berpikir kritis yang dipergunakan sebagai alat untuk mengukur berpikir kritis siswa dengan cara mengobservasi kegiatan pe-serta didik pada saat kegiatan pembelajar-an berlangsung. Sedangkan tes berupa soal memuat indikator pembelajaran sebagai alat ukur peningkatan hasil belajar siswa pada pelaksanaan pembelajaran yang berbentuk soal uraian.nTeknik analisis data menggunakan analisis deskriptif kualitatif dan kuantitatif.

\section{Hasil Penelitian}

Data hasil rubrik berpikir kritis dan hasil belajar siswa didapatkan setelah pelaksanaan penelitian siklus I dan siklus II dengan penggunaan model pembelajaran Problem Based Learning (PBL) di kelas 5 SDN 1 Ngambakrejo. Kegiatan tersebut menghasilkan data pelaksanaan siklus I dan siklus II sebagai berikut :

Tabel 2. Distribusi Frekuensi Kemampuan Berpikir Kritis Siswa Siklus 1

\begin{tabular}{|c|c|c|c|c|c|}
\hline \multirow[b]{2}{*}{ Jenjang } & \multirow[b]{2}{*}{ Kriteria } & \multicolumn{2}{|c|}{ Siklus 1} & \multicolumn{2}{|c|}{ Siklus 2} \\
\hline & & $\begin{array}{l}\text { frekue } \\
\text { nsi }\end{array}$ & $\begin{array}{l}\text { Persen } \\
\text { tase }\end{array}$ & $\begin{array}{c}\text { freku } \\
\text { ensi }\end{array}$ & $\begin{array}{c}\text { Persen } \\
\text { tase }\end{array}$ \\
\hline $128-104$ & $\begin{array}{c}\text { Sangat } \\
\text { baik }\end{array}$ & 0 & 0 & 1 & 3,7 \\
\hline $103-79$ & Baik & 12 & 44,4 & 11 & 40,7 \\
\hline $78-54$ & Cukup & 15 & 55,6 & 15 & 55,6 \\
\hline $53-32$ & Kurang & 0 & 0 & 0 & 0 \\
\hline \multicolumn{2}{|c|}{ Jumlah } & 27 & 100 & 27 & 100 \\
\hline \multicolumn{2}{|c|}{ Rata-rata } & \multicolumn{2}{|c|}{62,3} & \multicolumn{2}{|c|}{77} \\
\hline \multicolumn{2}{|c|}{ Skor maksimal } & \multicolumn{2}{|c|}{102} & \multicolumn{2}{|c|}{102} \\
\hline \multicolumn{2}{|c|}{ Skor minimal } & \multicolumn{2}{|c|}{57} & \multicolumn{2}{|c|}{57} \\
\hline
\end{tabular}


Tabel 2 menjelaskan terjadinya peningkatan presentase kemampuan berpikir kritis pada siswa dari siklus I ke siklus II setelah menerapkan model pembelajaran problem solving. Hasil observasi kemampuan berpikir kritis siswa menunjukkan bahwa pada siklus I, nilai rata-rata yang dihasilkan dari penilaian rubrik mencapai nilai rata-rata 62,3 , sedangkan hasil observasi kemampuan berpikir kritis siswa pada siklus II nilai ratarata mencapai 77 . Hal ini menunjukkan peningkatan dibandingkan dengan hasil obervasi pada siklus I.Dari penjelasan tersebut dapat dikaji bahwa peningkatan berpikir kitis terjadi pada siswa kelas 5 dengan menerapkan model pembelajaran problem based leraning (PBL). Penelitian ini juga sejalan dengan yang dilakukan Redhana dengan judul Penerapan Problem Based Learning Untuk Meningkatkan berfikir kritis mata pelajaran Matematika Siswa Kelas IV SDN Kauman Lor 01 Kecamatan Pabelan Kabupaten Semarang.

Tabel 3. Distribusi Frekuensi Hasil BelajarSiswa dengan Diterapkan Model Problem Based Learning

\begin{tabular}{ccccccc}
\hline \multirow{2}{*}{ Kategori } & \multicolumn{2}{c}{ Pra Siklus } & \multicolumn{2}{c}{ Siklus I } & \multicolumn{2}{c}{ Siklus II } \\
\cline { 2 - 7 } & $\begin{array}{c}\text { Jumlah } \\
\text { Siswa }\end{array}$ & $\begin{array}{c}\text { Persen } \\
(\%)\end{array}$ & $\begin{array}{c}\text { Sumlah } \\
\text { Siswa }\end{array}$ & Persen $(\%)$ & $\begin{array}{c}\text { Jumlah } \\
\text { Siswa }\end{array}$ & Persen (\%) \\
\hline Tuntas & 6 & 22,2 & 11 & 40,7 & 19 & 70,3 \\
\hline $\begin{array}{c}\text { Tidak } \\
\text { Tuntas }\end{array}$ & 21 & 77,8 & 16 & 59,3 & 8 & 29,7 \\
\hline Jumlah & 27 & 100 & 27 & 100 & 27 & 100 \\
\hline
\end{tabular}

Tabel 3 menjelaskan terjadinya peningkatan pada setiap siklus. Peningkatan berawal dari hasil Prasiklus dengan siswa yang tuntas sebanyak 6siswa dengan persentase 22,2 kemudian mengalami peningkatan di siklus I menjadi 11 siswa yang tuntas dengan persentase 40,7 kemudian terjadi peningkatan lagi pada siklus II menjadi 19 siswa yang tuntas dengan persentase 70,3. Pada aspek tidak tuntas mengalami pengurangan jumlah siswa, bermula dari prasiklus yang awalnya sejumlah 21 siswa dengan persentase 77,8 berkurang menjadi 16 siswa denga persentase 59,3 dan berkurang lagi pada siklus II menjadi 8 siswa dengan persentase $29,7 \%$. Dari uraian tersebut dapat dikaji bahwa peningkatan hasil belajar dapat dicapai dengan diterapkanya model Problem Based Learning (PBL). Penelitian ini telah melengkapi dan memperkuat kuat penelitian terdahulu seperti penelitian yang dilakukan oleh Vitasari dengan menerapkan model pembelajaran Problem Based Learning (PBL) dengan mengambil judul "Peningkatan Hasil Belajar Matematika melalui Model Problem Based Learning Siswa Kelas V SD Negeri 5 Kutosari”.

Menurut Nurdyansyah (2018) hasil belajar adalah sesuatu yang dicapai atau diperoleh setelah ia menerima pengalaman belajarnya. Hasil belajar sebagai pengukuran dan penilaian proses belajar mengajar. Salah satu penilaian untuk melihat hasil belajar adalah dilakukanlah tes. Tes tersebut dapat memberikan informasi sejauh mana penguasaan materi masing-masing peserta didik dalam mencapai tujuan pembelajaran. Hasil belajar siswa penelitian ini mengalami peningkatan yang mencapai nilai KKM. Pada prasiklus dalam penelitian ini dapat dilihat kategori tuntas hanya terdapat 6 siswa dengan persentase 22,2 , pada siklus pertama terdapat 11 siswa kategori tuntas dengan persentase 40,7. Dan pada siklus kedua terdapat 19 siswa kategori tuntas dengan persentase 70,3.

Swart dan Perkins (dalam Fisher,2012:3) menyatakan berfikir kritis bertujuan untuk mencapai penelitian yang kritis terhadap apa yang akan diterima atau dilakukan dengan alasan yang logis. Pada Penelitian ini, kenaikan kemampuan berpikir kritis sudah baik. Sudah mampu mengidentifikasi pertanyaan dan menemukan cara matematis untuk menyelesaikan pertanyaan.

Keunggulan yang termuat dalam penelitian ini yaitu pengunaan model Problem Based Learning pada mata pelajaran matematika yang diterapkan untuk meningkatkan kemampuan berpikir kritis peserta didik dan hasil belajar peserta didik. Pengukuran kemampuan berpikir kritis dengan menggunakan rubrik berpikir kritis. Hasil belajar peserta didik diukur mengunakan Soal uraian dengan tujuan dapat melihat proses identifikasi masalah dan proses penyelesaian yang detail sekaligus dapat melihat kemampuan berfikir kritis siswa dalam menyelesaikan 
masalah. Setelah diterapkanya model pembelajaran Problem Based Learning, kemampuan berpikir kritis dan hasil belajar peserta didik mengalami peningkatan, ditunjukan dengan hasil belajar peserta didik yang meningkat dan banyaknya peserta didik yang kritis dalam mengikuti pembelajaran. Seperti yang terlihat dalam penelitian ini bahwa siswa lebih aktif dalam proses menemukan jawaban atau pemahaman , dapat menganalisis pertanyaan dalam soal uraian dengan tepat, serta dalam menjawab pertanyaan tersusun sesuai dengan jawaban yang diharapkan sehingga mengakibatkan hasil belajar mengalami peningkatan. Selain itu pada proses kegiatan siswa mengikuti pembelajaran sesuai model Problem Based Learning sehingga siswa cenderung lebih aktif dapat menentukan permasalahan, mengemukakan hipotesis awal, menumpulkan data dan dapat menyimpulkan sendiri pemecahan masalah yang termuat dalam kegiatan pembelajaran.

Perbedaan penelitian ini dengan penelitian sebelumnya adalah penelitian ini bertujuan untuk meningkatkan kemampuan berpikir kritis dan hasil belajar siswa kelas 5. Karena dalam proses belajar mengajar, siswa dituntut untuk aktif mencari atau menemukan sendiri permasalahannya dan dalam menyelesaikan soal uraian siswa dituntut untuk dapat mengidentifikasi pertanyaan sehingga memacu siswa untuk berpikir kritis yang dapat mempengaruhi meningkatnya hasil belajar. Penelitian ini sejalan dengan sebelumnya dengan judul"Upaya peningkatan kemampuan berpikir kritis dan hasil belajar siswa melalui penerapan model pembelajaran Problem Based Learning dalam pembelajaran matematika" dilakukan oleh Nafiah dan Suyatno. Tujuan penelitian ini yaitu: memberikan peningkatan kemampuan berpikir kritis dan hasil belajar siswa dengan penggunaan Model Pembelajaran Problem Based Learning.

\section{Kesimpulan}

Sebelum melakukan penelitian, hasil belajar matematika (pra siklus) siswa kelas 5 SDN 1 Ngambakrejo masih belum mencapai tujuan hasil pembelajaran yang diharapkan. Pada kondisi awal siswa yang mendapatkan nilai tuntas dalam pembelajaran matematika hanya 6 siswa dengan persentase 22,2 , sedangkan siswa yang belum tuntas dalam pembelajaran berjumlah 21 siswa dengan persentase 77,8 . Dengan nilai rata-rata siswa 62 , untuk nilai tertinggi 88, dan terendah 33. Pada tes siklus I berjumlah 11 siswa tuntas dengan persentase 40,7 . Siswa yang belum tuntas dalam proses penelitian berjumlah 16 siswa dengan persentase 59,3. Dengan nilai ratarata siswa 66 nilai tertinggi 100 dan nilai terendah 45. Sedangkan siklus II terjadi peningkatan hasil belajar, hasil dari tes tingkat kelulusan berjumlah 19 siswa dengan persentase 70,3 , dan siswa yang tidak tuntas KKM adalah 8 siswa dengan persentase 29,7 . rata-rata nilai siswa 76 nilai tertinggi 100 dan nilai terendah 50 .

Pelaksanaan penelitian di kelas SDN 1 Ngambakrejo Kelas 5 menjadilandasan dalam penyampaian saran untuk Peneliti yang akan melakukan penelitian serupa yaitu disarankan lebih banyak mencari kajian dan referensi yang relevan agar lebih baik lagi dalam melakukan penelitian serta menjadi lebih lengkap lagi. Dan dalam mencari dan menggunakan model pembelajaran alangkah lebih baiknya menggunakan model pembelajaran yang inovatif, kreatif, aktif, serta menyenangkan yang dapat membuat senang siswa dalam kegiatan pembelajaran.

\section{Daftar Pustaka}

Fisher, Alec. 2012. Berpikir Kritis Sebuah Pengantar.Jakarta : Penerbit Erlangga.

Masitoh, S. (2016). Peningkatan Hasil Belajar IPS Melalui Strategi Inquiry Discovery Learning di Kelas IV SDN Kecamatan Cikarang Utara Kabupaten Bekasi. Jurnal Pendidikan Dasar UNJ, 7(2), 13-14.

Anugraheni, I. (2018). Meta Analisis Model Pembelajaran Problem Based Learning dalam Meningkatkan Keterampilan Berpikir Kritis di Sekolah Dasar [A Meta-analysis of Problem-Based Learning Models in Increasing Critical Thinking Skills 
in Elementary Schools]. Polyglot:

Jurnal Ilmiah, 14(1), 9-18.

Pramudita, W., \& Anugraheni, I. (2017).

Studi Penguasaan Matematika Dan

Bahasa Inggris Mahasiswa Program

Studi Pendidikan Guru Sekolah

Dasar (PGSD). Scholaria: Jurnal

Pendidikan Dan Kebudayaan, 7(1), 70-

82.

Kristin, F. (2016). Efektivitas Model

Pembelajaran Kooperatif Tipe

STAD Ditinjau Dari Hasil Belajar

IPS Siswa Kelas 4 SD. Scholaria:

Jurnal Pendidikan dan

Kebudayaan, 6(2), 74-79.

Pamungkas, A. D., Kristin, F., \& Anugraheni, I. (2018).

Meningkatkan Keaktifan Dan Hasil

Belajar Siswa Melalui Model

Pembelajaran Problem Based

Learning (Pbl) Pada Siswa Kelas 4

Sd. Naturalistic: Jurnal Kajian

Penelitian Pendidikan Dan

Pembelajaran, 3(1), 287-293.

Nurdyansyah, (2018). Pengaruh Strategi

Pembelajaran Aktif Terhadap Hasil

Belajar Pada Madrasah

Ibtidaiyah. Universitas

Muhammadiyah Sidoarjo.

Nafiah, Y. N., \& Suyanto, W. (2014). Penerapan model problem-based learning untuk meningkatkan keterampilan berpikir kritis dan hasil belajar siswa. Jurnal Pendidikan Vokasi, 4(1).

Vitasari, R. (2013). Peningkatan Hasil Belajar Matematika Melalui Model Problem Based Learning Siswa Kelas V SD Negeri 5 Kutosari. Kalam Cendekia PGSD Kebumen, 4(3).

Redhana, I. W. (2013). Model pembelajaran berbasis masalah untuk peningkatan keterampilan berpikir kritis. Jurnal Pendidikan dan Pengajaran, 46(1). 